\section{Regional disparities in} Andhra Pradesh, India

\section{A Amarender Reddy}

International Crops Research Institute for the Semi-Arid Tropics (ICRISAT), India

\section{MCS Bantilan}

International Crops Research Institute for the Semi-Arid Tropics (ICRISAT), India
Local Economy $0(0) 1-13$

(C) The Author(s) 2012

Reprints and permissions: sagepub.co.uk/journalsPermissions.nav DOI: $10.1177 / 026909421246379$ | lec.sagepub.com

\begin{abstract}
India is a federal union of 28 states. The states are further subdivided into districts. Andhra Pradesh is one of the largest states in India. This article examines how regional disparities in Andhra Pradesh have developed since its formation in 1956. A large urban centre (Hyderabad) which acts as a hub for economic activities, has attracted factors of production, and has stimulated income and employment opportunities in the surrounding local economy, but its impact on the peripheral districts is limited. There is a need for policy intervention in these peripheral districts in order to reduce regional disparities.
\end{abstract}

\title{
Keywords
}

Andhra Pradesh, India, regional development, regional disparities, regions

\section{Introduction}

Regional inequalities are a development challenge in most developing countries, especially those with large geographic areas under their jurisdiction. Following India's market liberalization in the early 1990s, skilled labour and capital in Andhra Pradesh have been drawn from the peripheral regions to the core regions, mostly attracted by the high-technology service sector. Meanwhile, unskilled workers, women, and the elderly remained in the low productivity and less capital intensive agricultural sector.
This article examines regional disparities in Andhra Pradesh and highlights the role played by its largest urban conglomeration (Hyderabad). It tries to answer the following questions:

(1) Have the regions and districts shown convergence or divergence over the last five decades?

\section{Corresponding author:}

A Amarender Reddy, ICRISAT, Patancheru 502324, Andhra Pradesh, India.

Email: a.amarenderreddy@cgiar.org 
(2) What is the pattern of change among different sub-sectors of industry, agriculture, and services sectors?

(3) What policy options would be effective in addressing regional disparities?

District level data on different development indicators are collected for the 23 districts of Andhra Pradesh state comprising three regions ${ }^{1}$ from the Andhra Pradesh Statistical Abstracts 1956-1958 and 20052007. All the prices are converted into 1999-2000 constant prices by using the wholesale price index series to calculate the changes in per capita income over the period. The analysis has been done by comparing averages for triennium ending (TE) 1958 and 2007 for various development indicators. Most of the comparisons are made on per capita terms and ratios which are unit free and comparable over the period and districts. Inter-district inequalities are quantified by a Gini concentration ratio (GCR).

\section{Overview of Andhra Pradesh and its regions}

Specific national, regional, and local conditions with specific cultural, historical, institutional, and political legacies all shape the particular experiences of sub-national territories and their economic and social development (Pike and Tomaney, 2004). Andhra Pradesh state is one of the largest states in India with a population of $84.6 \mathrm{~m}$ in 23 districts. The state was formed in 1956 by the merging of three regions, namely, Telangana, Coastal Andhra, and Rayalaseema. Telangana region occupies the largest geographical area of the state (42\%), followed by Coastal Andhra (34\%) and Rayalaseema (25\%). Population density is highest in Coastal Andhra $\left(367 / \mathrm{km}^{2}\right)$, followed by Telangana $\left(288 / \mathrm{km}^{2}\right)$ and Rayalaseema $\left(213 / \mathrm{km}^{2}\right)$.
In Figure 1, districts are grouped into poor, medium rich and rich, based on average monthly per capita expenditure, with $1.25 \mathrm{USD} /$ capita/day as poor, 1.26 to 2.00 USD/capita/day as medium-rich and above 2.00 USD/capita/day as rich. In 2004-2005, more than $10 \%$ of the rural population in Telangana lived in poverty in five out of 10 districts. In Rayalaseema three out of four districts fell into this category, but in coastal Andhra only two out of nine districts fell into this category. Telangana region has a larger share of scheduled castes and tribes (the most backward sections of society as recognized in the constitution of India), whose socio-economic conditions are far inferior to the upper caste population. Arguably, Telangana's development was held back by the long overhang of feudalism (the Nizam of Hyderabad), which meant that both coastal Andhra and Rayalaseema regions were more socially advanced in comparison, at the time of independence. However, even though human development indicators (see below) are at a higher level in both the Coastal Andhra and Rayalaseema regions, the former, the granary of south India, is prosperous due to its highly productive agricultural sector, while the latter is a drought-prone region with low land productivity, low population density, and low consumer demand (Reddy, 2010).

Hyderabad is a cosmopolitan urban centre, formed about 500 years ago, and located in the Telangana region. It constitutes $9.15 \%$ of the state population; the second largest city is Vishakhapatnam (only $2.04 \%$ ), followed by Vijayawada $(1.76 \%)$, both of which are located in Coastal Andhra. In addition to these three cities, about 45 urban centres exist, but with little agglomeration effects. Hence, Hyderabad attracts capital and labour not only from within the state, but also from other states and countries, especially on account of its concentration in IT industry 


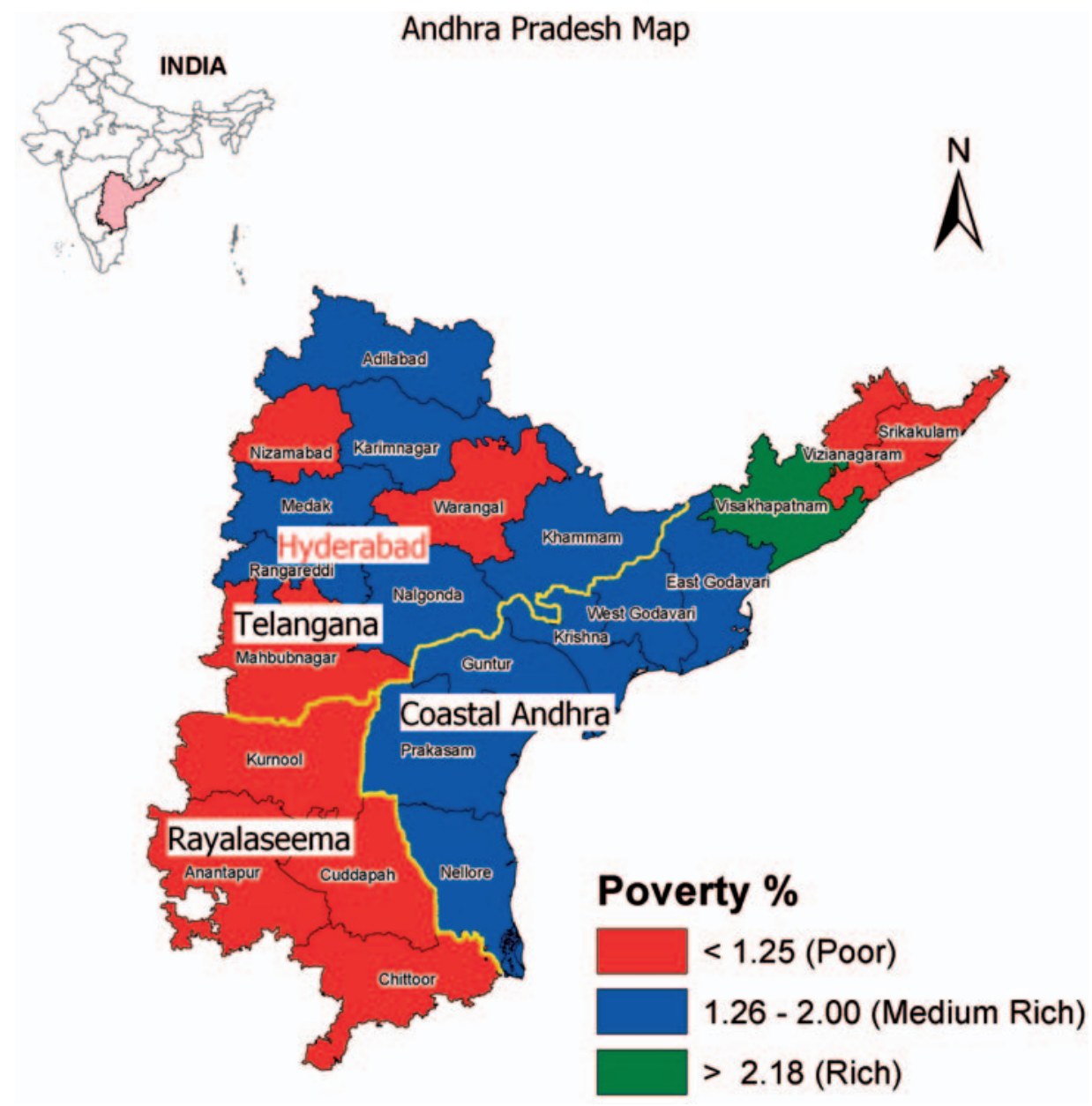

Figure I. Map of Andhra Pradesh India depicting district level poverty based on average monthly per capita expenditure (USD/capita/day).

and both public and private service sectors. Hyderabad city also has better public services like primary health centres, roads, and educated and highly skilled labour. Hence the gulf between Hyderabad and the poorer peripheral districts has widened.

\section{Sectoral composition of income and employment}

The development of the state's economy is indicated by the decrease in share of the agricultural sector in Gross State Domestic
Product (GSDP) from about 56\% in 1970 to about $27 \%$ in 2009 . However, the share of population dependent on the agricultural sector is stagnant at about $60 \%$, contrary to the experience of developed countries. In triennium ending (TE) 2008, the service sector contributed to about $45 \%$ of GSDP in Andhra Pradesh, while its share is $82 \%$ in Hyderabad (Figure 3). Agriculture contributed to about $24 \%$ of GDP in Telangana, $29 \%$ in Coastal Andhra and $27 \%$ in Rayalaseema. The growth rate of GSDP was $5.3 \%$ per annum between 1970 and 


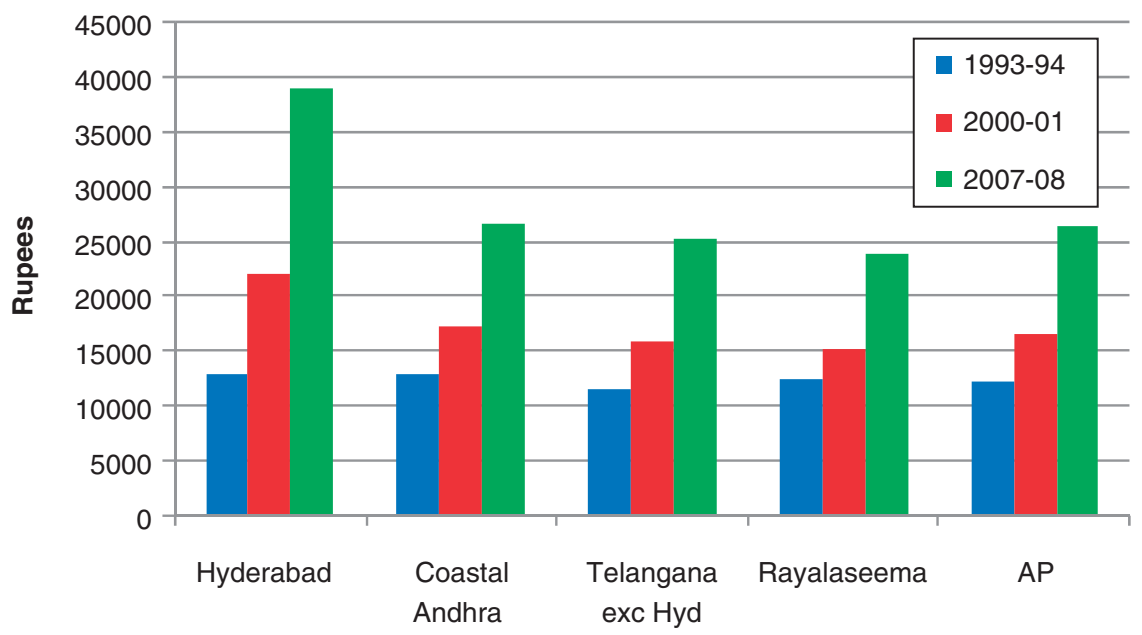

Figure 2. Per capita DDP at 1999-2000 constant prices.

2010, mainly driven by the service sector in Hyderabad.

Faster growth in the non-agricultural sector compared with the agricultural sector for an extended period and the concentration of the service sector in core cities has resulted in increased regional disparities in income between core (urban centres) and periphery (rural). Urbanization is higher in Telangana $(31 \%$ of the population lives in urban areas in Telangana including Hyderabad), followed by Coastal Andhra $(25 \%)$ and Rayalaseema (23\%) (Table 1). Districts surrounding the large urban centre of Hyderabad in Telangana region are experiencing exponential growth in per capita income from the non-agricultural sector due to a fast-growing urban population, in part stimulated by a 'home market effect' (Reddy, 2011). However, the high growth of Hyderabad (the core region) is not sufficient to increase per capita incomes of the remote peripheral districts, namely Adilabad, Nizamabad and Karimnagar within Telangana. Per capita income in Coastal Andhra is higher than Telangana (excluding Hyderabad), but the Telangana region has shown faster growth since 1999 due to the spread effects of Hyderabad
(Figure 2). Rayalaseema region is far behind both the coastal Andhra and Telangana regions. Per capita income is less in Rayalaseema where there is no 'home market effect' due to less population density, lower productivity agriculture and less purchasing power, and no large urban centre to support economic activity.

Per capita income both from the agriculture and non-agriculture sectors is highest in coastal Andhra, which indicates that agricultural income has complemented non-agricultural income in coastal Andhra through backward and forward integration and accumulation of consumption power among the population (Figure 3). Only Coastal Andhra has benefited from productivity enhancing technology in the 'green revolution' period (paddy) and the commercialization (such as fruits and vegetables, milk, and meat products) of agriculture due to its initial better resource endowment and subsequent public and private investment in the agricultural sector.

\section{Human development indicators}

Regional trends in population density, rural literacy, and work participation rates are 
Table I. Trends in population statistics 196|-2007.

\begin{tabular}{lcccc}
\hline Indicators & Year & Coastal Andhra & Telangana & Rayalaseema \\
\hline Total population (million) & $196 \mid$ & 16 & 12 & 6 \\
& 2007 & 34 & 33 & 14 \\
Population density/km ${ }^{2}$ & $196 \mid$ & 170 & 102 & 94 \\
& 2007 & 367 & 288 & 213 \\
\% of urban population & $197 \mid$ & 19 & 21 & 16 \\
& $200 \mid$ & 25 & 31 & 23 \\
Rural literacy rate (\%) & $196 \mid$ & 24 & 14 & 21 \\
Rural work participation rate (\%) & $200 \mid$ & 58 & 49 & 58 \\
& $196 \mid$ & 51 & 54 & 53 \\
Infant mortality rate (per 1000) & 2001 & 45 & 45 & 48 \\
\hline
\end{tabular}

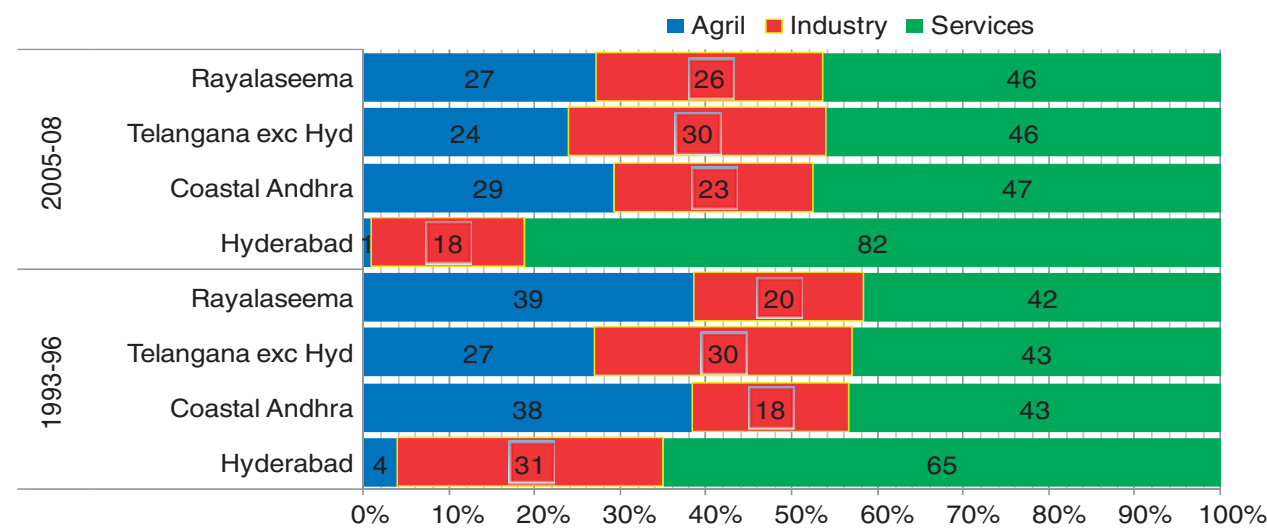

Figure 3. Sectoral share of GSDP.

presented in Table 1. In terms of human development indicators (rural literacy rate), Coastal Andhra and Rayalaseema have been ahead of Telangana since 1956, although the gaps between the Coastal Andhra and Telangana regions have reduced over the years. The faster increase in the share of population in Telangana reflects migration from other regions to Hyderabad. Population density is higher in developed Coastal Andhra compared to Telangana and Rayalaseema, in spite of out-migration from Coastal Andhra to Hyderabad, mostly financed by the agricultural surplus generated from the 'green revolution'. The higher population density of Coastal Andhra also helped increase consumption demand, which, in turn, supported non-agricultural activities. In comparison, the low population density and low-productive agriculture of Rayalaseema could not generate enough local demand to sustain non-agricultural employment and incomes. Binswanger et al. (1987), while studying developed countries over the period 1900-1984, concluded that in the short term, labour surpluses generated by improvements in agricultural productivity may not find employment in the modern sectors, but in 
the long term, the migration of labour to more productive non-agricultural sectors or large urban centres appears inevitable. This is reflected in the higher work participation rate $(48 \%)$ in Rayalaseema (which may be disguised unemployment) compared to both coastal Andhra and Telangana.

\section{The exorbitant growth of the core urban centre}

There is clear evidence that Hyderabad is the region's largest consumption centre. Its 'home market effect' makes it the main growth engine for Andhra Pradesh. This is evident from the share of sales tax collection of Hyderabad, which is $75 \%$ of total sale tax collection of Andhra Pradesh state (Table 2).

Andhra Pradesh state attracted 124bn rupees of FDI between 1991 and 2010, of which $51 \%$ was invested in Telangana, but with a very high concentration in Hyderabad city. Telangana region, excluding Hyderabad has received only $13 \%$ compared with $43.2 \%$ investments in coastal Andhra. Rayalaseema has received just $5.8 \%$ of FDI investments. Notably, Telangana (excluding Hyderabad) received relatively lower amounts of FDI, chiefly due to the concentration of investments in Hyderabad city.

Another good indicator of economic prosperity, intensity of business activity and social development, is the number of two-wheeler vehicles per 1000 population. Vehicle intensity is greatest in Hyderabad. However, Telangana (excluding Hyderabad) and coastal Andhra have uniform intensity, whereas in Rayalaseema there is low intensity of motor vehicles.

The share of non-agricultural workers is higher in coastal Andhra (42\%), but less in both Telangana and Rayalaseema - 38\% each in 2007-2008 (see Table 2) - while in Hyderabad $100 \%$ of workers depend on the non-agricultural sector. Rayalaseema has a much larger share of farmers than agricultural labourers, ${ }^{2}$ which is due to the low productive land and relatively poorer households that also own such land for

Table 2. Consumption and production trends in non-agricultural sectors.

\begin{tabular}{|c|c|c|c|c|}
\hline & Hyderabad & $\begin{array}{l}\text { Coastal } \\
\text { Andhra }\end{array}$ & $\begin{array}{l}\text { Telangana } \\
\text { excluding } \\
\text { Hyderabad }\end{array}$ & Rayalaseema \\
\hline $\begin{array}{l}\text { Share of sales tax collection Cross regions } \\
\text { TE } 2009 \text { (\% of the state) }\end{array}$ & 75 & 15 & 7 & 3 \\
\hline FDI in AP from 1991 to 2010 (\%of AP) & 38 & 43 & 13 & 6 \\
\hline $\begin{array}{l}\text { Two wheeler vehicles per } 1000 \text { population } \\
\text { in } 2009\end{array}$ & 252 & 72 & 71 & 54 \\
\hline $\begin{array}{l}\text { Share of non-agricultural workers in total } \\
\text { workforce (\%) }\end{array}$ & 100 & 42 & 38 & 38 \\
\hline Workers with above matriculation (\%) & 48 & 9 & 9 & 7 \\
\hline $\begin{array}{l}\% \text { of above matriculation who are engaged } \\
\text { in agriculture }\end{array}$ & 0 & 13 & 17 & 24 \\
\hline $\begin{array}{l}\text { Expenditure per student in Govt. degree } \\
\text { colleges (average of } 2006 \text { to } 2010 \text { in } \\
\text { rupees) }\end{array}$ & & 11558 & 7614 & 9192 \\
\hline
\end{tabular}

Source: Srikrishna Committee Report (20II). 
subsistence survival. The opposite is true for Coastal Andhra (Reddy, 2011).

About $47.9 \%$ of workers are educated above matriculation in Hyderabad, while this ranges between $7 \%$ and $9 \%$ in all three regions. Even though the share of highly educated (above matriculation) engaged in agriculture is low, there is significant regional variation ranging from $13 \%$ in coastal Andhra to $24 \%$ in Rayalaseema, with the lowest reported in Hyderabad (Srikrishna Committee Report, 2011). This indicates the lower employment opportunities in non-agricultural occupations for the highly educated in Rayalaseema region. It is interesting to note that the expenditure per student is higher in coastal
Andhra followed by Rayalaseema and Telangana, which possibly indicates the perceived higher returns to education and therefore greater investment in human capital in the developed region, thereby reinforcing regional disparities.

Figure 4 presents the district-wise decadal population growth in Andhra Pradesh from 2001 to 2011(RGI, 2011). In general, the male population in urban areas increased much faster than the rural population. The districts near Hyderabad city (which actually fall under Hyderabad Metropolitan Developmental Authority), that is Rangareddy, Medak, Mahboobnagar, and Nalgonda, showed higher increase in decadal growth rate of

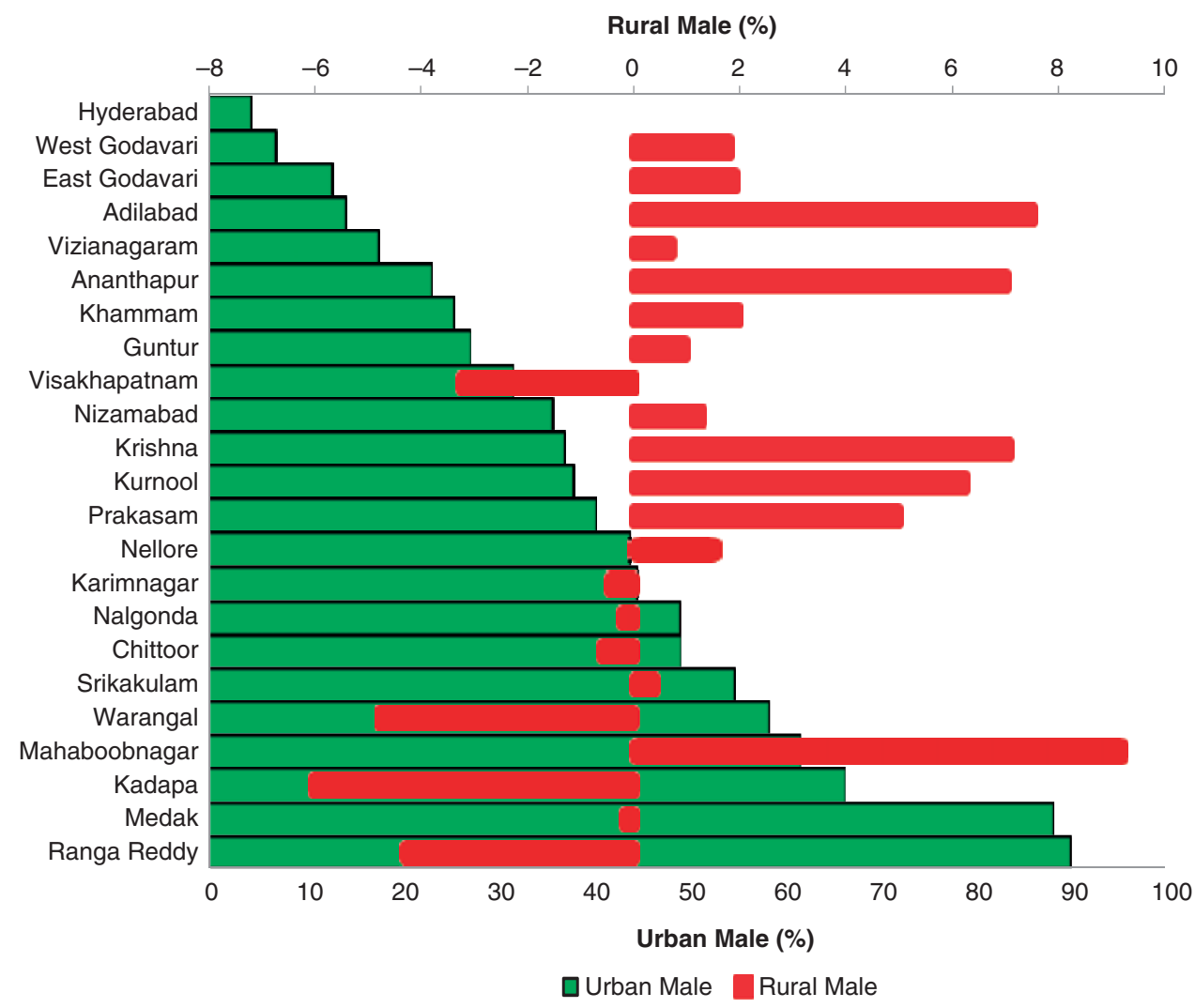

Figure 4. District-wise decadal growth rate of population 200I-20II. 
the male urban population. It is also interesting that some of the most prosperous districts, east Godavari and west Godavari districts, showed much less increase in the urban-male population along with remote districts like Adilabad, Vijayanagaram, and Anantapur.

Most of the high-growth industries generate employment particularly in large urban centres and mostly among males the majority of the rural workers migrated to urban centres to acquire the necessary skills. Construction, followed by textiles, IT and IT enabled services (ITES), health care, tourism, drugs and pharmaceuticals, banking and insurance, engineering, mines and minerals, food processing, chemicals and fertilizers, and biotech are among the fastest growing industries which absorb large numbers of employees mostly in urban and semi-urban areas (Table 3). The largest growth is expected from IT and ITES, biotech, healthcare, textiles, engineering, and pharmaceuticals.

\section{Land use pattern, geographical advantage, and agricultural growth}

Palmer-Jones and Sen (2003) have stressed the importance of initial conditions in determining the rate of agricultural growth in rural India. In Telangana, only $40 \%$ of the total geographical area is used for agriculture and a large portion $(23 \%$ of total geographical area) is fallow land (cultivable, but not cultivated in the reporting year). This large area of fallow land in Telangana is a sign of the neglect of the agricultural sector and a lack of investments in land development measures over the last five decades (Figure 5). The larger irrigated area in Coastal Andhra can be attributed to higher public investments in irrigation, which is facilitated by its lower gradient and higher rainfall.

The change in land productivity from 1958 to 2007 at constant prices of 19992000 is given in Table 4. The total value of

Table 3. Human resource requirements span out in Andhra Pradesh for high growth industries.

\begin{tabular}{llll}
\hline & & & Projected \\
employment & Employment & Incremental \\
Key industries & in 20II (in 000) & $\begin{array}{l}\text { growth (\%) in } \\
\text { Human Resources }\end{array}$ \\
bonstruction & 2200 & 4210 & (in 000) \\
requirement till 20I5
\end{tabular}

Source: Planning Commission (2011). 
agriculture (crop plus livestock/ha) large number of agricultural labourers per increased from Rs16,265 to Rs49,668 in 1000 hectares of net cropped area (517), Coastal Andhra, from Rs8647 to Rs23,087 which is almost double that of in Rayalaseema, and from Rs5846 to 32,328 Rayalaseema region (267). This again indiin Telangana. Coastal Andhra supports a cates the higher employment generation

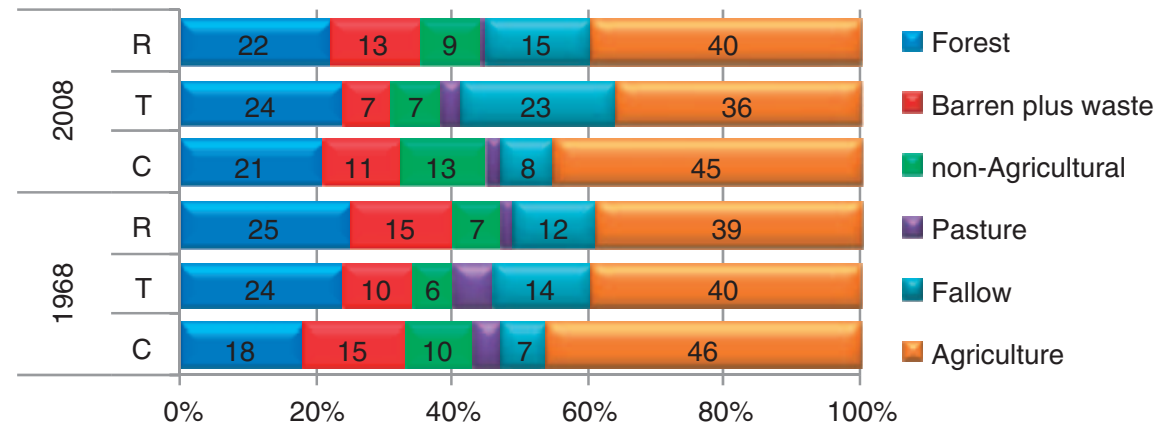

Figure 5. Land use pattern (\% of total geographical area).

Table 4. Trends in agricultural production (1958-2007).

\begin{tabular}{|c|c|c|c|c|}
\hline Indicator & Year & Coastal Andhra & Telangana & Rayalaseema \\
\hline \multirow[t]{2}{*}{ Value of agricultural production (Rs/ha) } & TE 1958 & 16265 & 5846 & 8647 \\
\hline & TE 2007 & 49668 & 32328 & 23087 \\
\hline \multirow[t]{2}{*}{ Number of agricultural labourers/I000 ha } & TE 1958 & 234 & 134 & 134 \\
\hline & TE 2007 & 517 & 292 & 267 \\
\hline \multirow[t]{2}{*}{ Number of cultivators/I000 ha } & TE 1958 & 250 & 184 & 175 \\
\hline & TE 2007 & 234 & 259 & 200 \\
\hline \multirow[t]{2}{*}{ Mechanization (number of tractors//000 ha) } & TE 1958 & 0.39 & 0.26 & 0.10 \\
\hline & TE 2007 & 9.20 & 7.21 & 5.19 \\
\hline Per capita DDP (Rs) & TE 2007 & 26356 & 23715 & $|867|$ \\
\hline Per capita DDP (Rs) of largest city in the region & TE 2007 & 33980 & 35776 & 19179 \\
\hline \multirow[t]{2}{*}{ Net cropped area (NCA) (I000 ha) } & TE 1958 & 3072 & 3932 & 2427 \\
\hline & TE 2007 & 3944 & $4|8|$ & 2800 \\
\hline \multirow[t]{2}{*}{ Net irrigated area (NIA) (\%) } & TE 1958 & 58 & 19 & 18 \\
\hline & TE 2007 & 56 & 40 & 22 \\
\hline \multirow[t]{2}{*}{ Electricity consumption (kwh/capita) } & TE 1973 & 59 & 31 & 48 \\
\hline & TE 2007 & 478 & 779 & 572 \\
\hline \multirow[t]{2}{*}{ Fertilizer consumption $(\mathrm{kg} / \mathrm{ha})$} & TE 1958 & 17 & 7 & 7 \\
\hline & TE 2007 & 294 & 211 & 119 \\
\hline \multirow[t]{2}{*}{ Rice (kg/ha) } & TE 1958 & 1004 & 778 & 1292 \\
\hline & TE 2007 & 3219 & 2980 & 3040 \\
\hline \multirow[t]{2}{*}{ Groundnut (kg/ha) } & TE 1958 & 959 & 581 & 971 \\
\hline & TE 2007 & 1383 & 1293 & 763 \\
\hline \multirow[t]{2}{*}{ Cotton $(\mathrm{kg} / \mathrm{ha})$} & TE 1958 & 922 & 339 & 168 \\
\hline & TE 2007 & 3045 & 2057 & 1234 \\
\hline
\end{tabular}


Table 5. Trends in Gini concentration ratio of districts.

\begin{tabular}{llllll}
\hline Item & TE 1958 & TE 2007 & Sector & $1999-2000$ & 2007-2008 \\
\hline Crop production & 0.301 & 0.202 & Agriculture & 0.103 & 0.076 \\
Paddy area & 0.177 & 0.238 & Industry & 0.037 & 0.017 \\
Legumes area & 0.286 & 0.379 & Services & 0.031 & 0.024 \\
Gross irrigated area (GIA) & 0.043 & 0.079 & GDDP & 0.036 & 0.035 \\
\hline
\end{tabular}

Note: GCR near to I indicates higher inequality, near to zero indicates equality.

capacity of the farm sector in the agriculturally advanced region despite significant mechanization, compared with the low productivity regions. The per capita district domestic product (DDP) is also much higher in coastal Andhra than Telangana and Rayalaseema. It is interesting to note that the gap in DDP between each region and its largest city is much higher in Telangana, but almost negligible in Rayalaseema, where there is no big city to attract skilled labour and capital. The productivity of three major crops (paddy, groundnut, and cotton) is higher in coastal Andhra, while Rayalaseema and Telangana regions showed mixed trends (Reddy and Bantilan, 2012).

A set of GCRs, calculated from district level data on agricultural production for two crop groups (paddy and legume), and gross irrigated area (GIA) are presented in Table 5. The Gini ratio increased for both paddy and legume crops, while for total crop production (in value terms) it decreased. However, the Gini ratio increased for GIA showing that the benefits from land improvement/irrigation are increasingly concentrated in a few districts. This shows that districts were increasingly specialized in growing crops based on their comparative advantage, although to some extent it helped in the convergence of districts in their agricultural production. However, GCRs decreased in sectoral district domestic production for all three sectors (namely agriculture, industry, and services).

\section{Regional policies and public and private sector investment}

Regional-wide disaggregation of revenue and expenditures is given in Table 6. The share of the largest urban centre (Hyderabad) in state revenue is nearly $50 \%$, followed by Telangana and coastal Andhra and Rayalaseema. It shows that the urban centre and its surrounding districts are contributing a larger chunk of state revenues, while the agricultural-based regions' share is negligible. However, when it comes to state expenditure, distribution is more egalitarian. This signifies the state and public policy role in funding under developed regions.

Table 7 summarizes the regional dispersion of investments in health and electricity. It shows that total per capita connected load for Telangana region was the highest, owing to demand for electricity in Telangana region being higher compared with other regions which the electricity department is meeting. In Telangana region, agricultural power consumption in $\mathrm{KWH}$ (MUs) per capita is higher compared with Rayalaseema and coastal Andhra regions. The electricity supply for the agricultural sector is provided at highly subsidized rates in the state. The higher power consumption in Telangana is attributed to dominance of tube-well irrigation which requires electricity to pump water from deeper soils (through private investment), unlike canal irrigation (which flows through gravitation and does not require electricity) 
Table 6. Regional share in revenue from important taxes and non-taxes, and expenditure on important services (\%).

\begin{tabular}{|c|c|c|c|c|c|c|c|c|c|c|}
\hline \multirow[b]{2}{*}{ Year } & \multicolumn{5}{|c|}{ Revenue from 4 sources } & \multicolumn{5}{|c|}{ Expenditure on 8 services } \\
\hline & Hyderabad & C & $\mathrm{T}$ & $\mathrm{R}$ & AP & Hyderabad & C & $\mathrm{T}$ & $\mathrm{R}$ & AP \\
\hline 2004 & 34 & 20 & $4 I$ & 5 & $100(139.0)$ & 3 & 33 & 44 & 20 & $100(65.4)$ \\
\hline 2005 & 47 & 20 & 28 & 5 & $100(170.6)$ & 2 & 29 & 48 & 21 & $100(84.1)$ \\
\hline 2006 & 47 & 18 & 30 & 5 & $100(199.4)$ & I & 30 & 49 & 20 & $100(126.2)$ \\
\hline 2007 & 46 & 18 & 31 & 5 & $100(197.3)$ & I & 27 & 48 & 24 & $100(109.0)$ \\
\hline
\end{tabular}

Sources: Andhra Jyothi Online, Hyderabad March 23, 2007; Vaartha, April 15, 2008 and Socio-Economic Survey of AP 2007-2008.

Notes I: The four income sources of revenue are: sales tax, state excise, stamps and registration, and transport.

2: The 8 important expenditure services are: agriculture, rural development, irrigation, education, medical \&health, water supply \& sanitation, housing, \& welfare (including minorities).

3: Figures in brackets are Rs bn.

Table 7. Region-wise public sector investment in health and electricity consumption.

\begin{tabular}{|c|c|c|c|c|c|c|}
\hline \multirow[b]{2}{*}{ Region } & \multicolumn{2}{|c|}{$\begin{array}{l}\text { No. of primary } \\
\text { health centres (PHCs) } \\
\text { per million rural } \\
\text { population }\end{array}$} & \multicolumn{2}{|c|}{$\begin{array}{l}\text { Total connected load } \\
\text { (watt/capita) }\end{array}$} & \multicolumn{2}{|c|}{$\begin{array}{l}\text { Agricultural power } \\
\text { consumption in kwh/capita }\end{array}$} \\
\hline & 1999 & 2009 & 1972 & 2009 & 1972 & 2009 \\
\hline Coastal Andhra & 27.5 & 25.1 & 58.5 & 436.9 & II.I & 82.3 \\
\hline Telangana & 29.4 & 25.3 & 48.7 & 463.0 & 9.7 & 256.5 \\
\hline Rayalaseema & 33 & 26.9 & 69.1 & 344.6 & 22.6 & 237.7 \\
\hline
\end{tabular}

in coastal Andhra. Again, public spending in health and electricity indicates that public investment is more egalitarian, and in many cases helped to reduce regional disparities.

Tractors, electric pump sets and irrigated area are three important inputs in the agrarian economy. There was a shift of many districts in their relative position between 1956 and 2007 from low-to-high in electric pumps and fertilizer in the Telangana region compared with Coastal Andhra, but although this increased the irrigated area and productivity, it also raised the cost of production. In the use of farm machinery and other inputs the Telangana districts have also caught up, but Rayalaseema districts have lagged behind.
Rayalaseema has the highest density of bank accounts with 127 accounts per 1000 rural population, followed by the coastal areas at 110 and Telangana at 85 mainly due to a pro-active initiative of public sector banks to open bank accounts in backward areas, but credit flows through formal credit institutions are higher in the Coastal Andhra region (Srikrishna Committee Report, 2011), which exacerbates the already existing regional disparities in capital investments.

Overall, land productivity, per capita income, and irrigated area as a percentage of GCA have been higher in coastal Andhra, followed by Telangana and Rayalaseema. Coastal Andhra is 
prosperous agriculturally due to its natural advantage and also due to favorable government policies during the last five decades (Reddy, 2010). Overall, the gap between Coastal Andhra and Telangana is still high in many developmental indicators and needs to be reduced, while Rayalaseema has lagged behind in the development process.

Rayalaseema region, which ranked next to the Coastal region in the beginning of the period, has slipped to third position, being overtaken by the Telangana region which now ranks next to the Coastal region. The reasons for shift in ranking of these two regions are the poor resource endowments of Rayalaseema and considerable under-utilization of resources in the relatively better endowed Telangana under the earlier feudal set up, followed by a release of productive forces consequent on the abolition of the princely state, its merger with the rest of the country after independence, and the development of the large urban centre of Hyderabad.

\section{Conclusion and discussion: Policies for balanced development}

Regional growth patterns in Andhra Pradesh do not conform to assumptions regarding adjustments in wages or returns to capital which would eventually lead to regional economic convergence, at least in the time period studied here. In contrast, a process of cumulative causation is apparent, in which agglomeration has stimulated innovation and productivity growth, further accelerating the attraction of factors to the leading, or core, region. Early versions of cumulative growth (or growth pole theory) can be found in the writings of Myrdal (1957), with later elaborations by Kaldor (1970), Hirschman (1958) and Krugman (1991,1998), all of which suggest a deepening, in the absence of intervention, in core- periphery disparities, especially in the context of greater market liberalization.

The question remains what type of intervention would help reduce regional imbalances in Andhra Pradesh. As Scott (2000: 116) argues 'successful development programs must inevitably be judicious combinations of general principles and localized compromises, reflecting the actual geography and history of each individual region'. Among the specific polices that would be beneficial to balanced regional growth in Andhra Pradesh are the development of better communications between the core-urban centre and remote rural peripheries in order to encourage agricultural productivity and lower transaction costs for enterprises in the periphery, and innovative financial instruments for financing public-private partnership infrastructure projects in under-developed regions. Some policy options for the development of backward areas are not controversial, for example investment in education and skilled development including quality education and health facilities, better transparency and governance and the expansion of financial services. However, the success of the 'green revolution' technology hastened by irrigation facilities in Coastal Andhra cannot be replicated in regions that are not geographically similarly advantaged. The poorer districts of Rayalaseema and Telangana require quite different policy interventions, for example encouraging less water-intensive rain-fed crops, livestock, and non-agricultural employment. Social support programmes for women and the elderly need to be encouraged. Development policies must focus on the peripheral regions with more autonomy to local planning and decision-making bodies. Local elected bodies are better positioned to identify and exploit local opportunities and to plan effective strategies, but lagging regions like Rayalaseema could benefit from empowered regional development councils. 
Future research should concentrate on these questions: first, how is the relative importance of agriculture as the engine of rural development versus the non-farm activities changing in each region? Second, what should be the strategy of small farmers in the face of relative decline in incomes from the agricultural sector? And, finally, what will be the governance and implementation challenges of public programmes?

\section{Acknowledgements}

This article is drawn from 'Study of Spatial and Temporal Dynamics of Labour Market Behaviour by Using Household Panel Data of ICRISAT' funded by CGIAR. Thanks are also due to Professor D Narasimha Reddy for his suggestions on how to improve the article.

\section{Notes}

1. The Telangana districts are: Mahbubnagar, Hyderabad (Rangareddy + Hyderabad), Medak, Nizamabad, Adilabad, Karimnagar, Waranagal, Khammam and Nalgonda; the four districts of Rayalaseema are: Chittoor, Kadapa, Anantapur, and Kurnool; the nine districts of Coastal Andhra are: Srikakulam, Visakhapatnam (Visakhapatnam + Vizianagaram), East Godavari, West Godavari, Krishna, Guntur (Guntur + Prakasam), and Nellore.

2. An agricultural labourer is defined as a person between 15 and 59 years old whose major share of income is from wages earned by working on others' farms, while a cultivator is defined as a person whose major share of yearly income comes from farming their own land.

\section{References}

Binswanger $\mathrm{H}$, Yang $\mathrm{MC}$, Bowers $\mathrm{A}$, et al. (1987) On the determinants of cross-country aggregate agricultural supply. Journal of Econometrics 36(1/2): 111-131.

Hirschman AO (1958) The Strategy of Economic Development. New Haven, CT: Yale University Press.
Kaldor N (1970) The case for regional policies. Scottish Journal of Political Economy 17(3): 337-348.

Krugman P (1991) Increasing returns and economic geography. Journal of Political Economy 99(3): 483-499.

Krugman P (1998) What's new about the new economic geography. Oxford Review of Economic Policy 14(2): 7-17.

Myrdal G (1957) Economic Theory and Underdeveloped Regions. London: Duckworth.

Palmer-Jones R and Sen K (2003) What has luck got to do with it? A regional analysis of poverty and agricultural growth in rural India. Journal of Development Studies 40(1): 1-31.

Pike A and Tomaney J (2004) Guest editorial: Subnational governance and economic and social development. Environment and Planning A 36(12): 2091-2096.

Planning Commission (2011) A presentation before the Deputy Chairman, Planning Commission and the Chief Minister of Andhra Pradesh, 6 May 2011, Yojana Bhavan, New Delhi. Available at: http://planningcommission.nic.in/plans/stateplan/present/Andhra_Pradesh.pdf (accessed 2 October 2012).

Reddy AA (2010) Disparities in agricultural productivity growth in Andhra Pradesh. Indian Economic Journal 58(1): 134-152.

Reddy AA (2011) Disparities in employment and income in rural Andhra Pradesh, India. Bangladesh Development Studies XXXIV(3): 73-96.

Reddy AA and Bantilan MCS (2012) Competitiveness and technical efficiency: Determinants in the groundnut oil sector of India. Food Policy 37(3): 255-263.

RGI (2011) Census Info India Dashboard. Available at: http://www.censusindia. gov.in/ 2011-common/census_info.html (accessed 5 September 2011).

Scott AJ (2000) Regions and World Economy: The Coming Shape of Global Production, Competition and Political Order. Oxford: Oxford University Press.

Srikrishna Committee (2011) Report of Committee for Consultation on the Situation in Andhra Pradesh. New Delhi: Government of India. Available at: http://data.ndtv.com/downloads/ report.pdf (accessed 28 September 2012). 